\title{
KETAHANAN PANGAN RUMAH TANGGA BERDASARKAN PENDAPATAN PETANI JAGUNG MANIS DI DESA BULUPOUNTU JAYA KECAMATAN SIGI BIROMARU
}

\author{
Veki Vernando, Sri Jumiyati", Syaiful Bachri \\ Program Studi Agribisnis, Fakultas Pertanian, Universitas Muhammadiyah Palu \\ Jl. Jabal Nur No. 1 Palu 94116 \\ *Corresponding author: srijumiyati1068@gmail.com
}

\begin{abstract}
Food is a basic need for humans to survive, and therefore adequate food for everyone is a basic right that deserves to be fulfilled. One of the important indicators affecting the food security status of farmer households is income. This study aims to determine the amount of income obtained from maize farming and the value of household food security of maize farmers in the Bulupountu Jaya Village, Sigi Biromaru District, Sigi Regency. The research was conducted from July to September 2020. The analytical method used is a descriptive based on the farm household income, staple food needs, and local staple food prices. The results showed that the income received by maize farmers for one planting season was IDR 6,384,691.85/farmer or IDR 5,010,159.76/ha with revenue of IDR 10,182,692.31/farmer or IDR 13,441,153.85/ha. Meanwhile, the total production cost incurred is IDR 3,798,000.46/farmer or IDR 5,010,159.76/ha. The farm household income from outside maize farming comes from livestock businesses amounting to IDR 5,007,692.31 and as a laborer an amount of IDR 5,215,384.61, with a total side income of IDR 10,223,076.92. Farm household food security shows a value greater than 1 ( $Z>1$ ), amounting to IDR 9,250,776.92, which means that maize farmer households with a side business will have a food security condition in a year and have an excess of IDR.9,250,776.92, to buy necessities other than staple food (rice).
\end{abstract}

Keywords: income, food security, farming, maize

\begin{abstract}
Abstrak: Pangan merupakan kebutuhan mendasar bagi manusia untuk dapat mempertahankan hidup, dan karenanya kecukupan pangan bagi setiap orang merupakan hak asasi yang layak dipenuhi. Salah satu indikator penting yang memengaruhi status ketahanan pangan rumah tangga petani adalah pendapatan. Penelitian ini bertujuan untuk mengetahui besarnya pendapatan yang diperoleh dari usahatani jagung manis dan nilai ketahanan pangan rumah tangga petani jagung manis di Desa Bulupountu Jaya Kecamatan Sigi Biromaru Kabupaten Sigi. Penelitian dilaksanakan mulai bulan Juli sampai September 2020. Metode analisis adalah deskriptif berdasarkan pendapatan rumah tangga petani, kebutuhan pangan pokok dan harga pangan pokok setempat. Hasil penelitian menunjukkan bahwa pendapatan yang diterima petani jagung manis untuk satu kali musim tanam adalah sebesar Rp6.384.691,85/petani atau sebesar Rp5.010.159,76/ha dengan penerimaan sebesar Rp10.182.692,31/petani atau Rp13.441.153,85/ha. Sedangkan total biaya produksi yang dikeluarkan sebesar Rp3.798.000,46/petani atau Rp5.010.159,76/ha. Pendapatan rumah tangga petani dari luar usahatani jagung manis berasal dari usaha ternak sejumlah Rp5.007.692,31 dan sebagai buruh sejumlah Rp5.215.384,61 dengan total pendapatan sampingan sejumlah Rp10.223.076,92. Ketahanan pangan rumah tangga petani jagung manis menunjukkan nilai lebih besar daripada $1(Z>1)$, sejumlah Rp9.250.776,92, yang berarti bahwa rumah tangga petani jagung manis dengan usaha sampingan akan memiliki kondisi ketahanan pangan dalam setahun dan memiliki
\end{abstract}


kelebihan dana sebesar Rp9.250.776,92 untuk membeli kebutuhan lain selain bahan pangan pokok (beras).

Kata kunci: pendapatan, ketahanan pangan, usahatani, jagung manis

\section{PENDAHULUAN}

Pangan merupakan kebutuhan mendasar bagi manusia untuk dapat mempertahankan hidup dan karenanya kecukupan pangan bagi setiap orang setiap waktu merupakan hak asasi yang layak dipenuhi (Gundersen et al., 2011). Berdasarkan kenyataan tersebut masalah pemenuhan kebutuhan pangan bagi seluruh penduduk setiap saat di suatu wilayah menjadi sasaran utama kebijakan pangan bagi pemerintah suatu negara (Atem dan Niko, 2020). Indonesia termasuk negara tropis dengan sinar matahari yang cukup dan tanah yang subur sehingga potensial menjadi daerah pertanian yang baik. Alam dan kesuburan bumi Indonesia merupakan modal pembangunan yang harus dirawat dan dikelola untuk memenuhi kebutuhan pangan seluruh masyarakat (Wahyunto et al., 2013). Hal ini telah muncul dalam tekad (visi) Kementerian Pertanian, yaitu mewujudkan ketahanan pangan dan kesejahteraan petani (Syahyuti et al., 2016). Pembangunan pertanian dicanangkan oleh pemerintah tidak lagi fokus pada persoalan produksi semata (Jumiyati et al., 2018). Pembangunan ketahanan pangan adalah mencapai ketahanan dalam bidang pangan dalam kondisi terpenuhinya pangan bagi setiap individu/ rumah tangga dari produksi pangan nasional, yang tercermin dari tersedianya pangan yang cukup, jumlah dan mutu, aman, merata dan terjangkau di seluruh wilayah Indonesia (Suharyanto, 2011). Pangan merupakan kebutuhan dasar manusia untuk dapat hidup dan melakukan aktivitas seharihari, sedangkan ketahanan pangan adalah jaminan bagi manusia untuk hidup sehat dan bekerja secara produktif (Saliem dan Ariani, 2016).

Definisi atau pengertian ketahanan pangan versi Negara Republik Indonesia telah dirumuskan dalam UU pangan dengan mengacu pada berbagai definisi yang berlaku di Indonesia dan di masyarakat internasional, para penyusun UU pangan merumuskan batasan ketahanan pangan yang didalamnya merangkum beberapa butir penting sebagai berikut: 1) terpenuhinya kebutuhan pangan bagi negara sampai tingkat perseorangan, 2) tolak ukur terpenuhinya kebutuhan pangan meliputi berbagai aspek yaitu: a) dari sisi kuantitas jumlahnya cukup, b) dari sisi kualitas mutunya baik, aman dikonsumsi, jenis pangan tersedia beragam, memenuhi kecukupan gizi, c) dari sisi keamanan pangan rohani, pangan harus tidak bertentangan dengan kaidah agama, keyakinan dan budaya masyarakat, serta d) dari sisi keterjangkauan ekonomi, pangan tersedia merata ke seluruh pelosok Indonesia dengan harga terjangkau oleh seluruh komponen masyarakat, dan 3) penyediaan dan keterjangkauan pangan ini dimaksudkan agar masyarakat sampai perseorangan dapat hidup sehat, aktif, dan produktif secara berkelanjutan (Suryana, 2014). Banyak indikator yang dapat digunakan untuk melihat ketahanan pangan, satu diantaranya adalah pangsa pengeluaran pangan penduduk (Pangaribowo et al., 2013).

Ketahanan pangan di tingkat nasional mencakup penyediaan pangan dalam jumlah dan kualitas yang cukup dan terstandar dengan harga terjangkau oleh masyarakat khususnya masyarakat pedesaan (Prabowo, 2010). Hal ini dikarenakan basis konsep ketahanan pangan adalah rumah tangga khususnya di wilayah pedesaan. Isu kerawanan pangan akan memengaruhi keberhasilan pembangunan nasional yang dianggap gagal dalam mensejahterakan masyarakat yang salah satu indikatornya adalah masyarakat tersebut berkecukupan pangan baik yang dihasilkan sendiri maupun yang mampu diaksesnya dengan lancar (Burchi dan Muro, 2012). Fenomena kenaikan harga pangan akan memberikan dampak negatif terhadap kesejahteraan masyarakat bahkan dapat meningkatkan angka kemiskinan masyarakat (Gustafson, 2013). Kemiskinan merupakan masalah yang terus berlanjut di Indonesia, terutama di pedesaan (Jumiyati, 2019a). Kemiskinan adalah penyebab kelaparan, marginalisasi, penelantaran dan masalah sosial lainnya (Zahra dan Zafar, 2015). Kini saatnya Indonesia berupaya lepas dari masalah kelaparan dengan membangun ketahanan 
Vernando, V., Jumiyati, S., Bachri, S. : Ketahanan Pangan Rumah Tangga ...

Tabel 1. Luas panen, produksi, dan produktivitas jagung manis menurut Kabupaten/Kota di Provinsi Sulawesi Tengah

\begin{tabular}{lrrr}
\hline Kabupaten/Kota & Luas Panen (ha) & Produksi (ton) & Produktivitas (ton/ha) \\
\hline Banggai Kepulauan & 117 & 392 & 3,35 \\
Banggai & 2.907 & 10.676 & 3,67 \\
Morowali & 410 & 1.865 & 4,54 \\
Poso & 2.335 & 8.510 & 3,64 \\
Donggala & 2.402 & 9.637 & 4,01 \\
Toli Toli & 413 & 1.391 & 3,37 \\
Buol & 1.188 & 5.635 & 4,74 \\
Parigi Moutong & 4.508 & 20.069 & 4,45 \\
Tojo Una-Una & 8.229 & 37.495 & 4,56 \\
Sigi & 8.470 & 27.580 & 3,26 \\
Banggai Laut & 35 & 114 & 3,26 \\
Morowali Utara & 779 & 3.696 & 4,74 \\
Palu & 709 & 4.063 & 5,73 \\
\hline Jumlah & 32.502 & 131.123 & \\
\hline
\end{tabular}

Sumber: BPS Provinsi Sulawesi Tengah, 2019

pangan melalui upaya peningkatan pendapatan usahatani yang dikelola oleh para petani pedesaan (Swastika, 2011).

Produksi jagung manis di Provinsi Sulawesi Tengah mencapai 380 ribu ton dengan daerah penghasil Kabupaten Tojo Unauna, Poso dan Buol. Kemudian tahun 2019 terjadi kenaikan produksi sebesar 100 ribu ton, dengan daerah pengembangan Kabupaten Morowali Utara, Sigi, Donggala dan Banggai. Realisasi produksi ini diharapkan dapat memberikan kontribusi terhadap kelangsungan ketahanan pangan daerah dan memberikan dampak positif terhadap pertumbuhan ekonomi daerah (Pawlak dan Kołodziejczak, 2020). Data luas panen, produksi dan produkstifitas tanaman jagung manis Provinsi Sulawesi Tengah secara rinci disajikan pada Tabel 1 .

Berdasarkan Tabel 1, terlihat bahwa produksi tanaman jagung manis di Kabupaten Sigi sebesar 27.580 ton dan luas panen 8.470 ha dengan produktivitas 3,26 ton/ha, berada pada urutan ke-2 dari 13 kabupaten/kota yang ada di Provinsi Sulawesi Tengah. Selanjutnya dari 15 kecamatan yang berada Selanjutnya dari 15 kecamatan yang berada di Kabupaten Sigi, Kecamatan Sigi Biromaru berada pada urutan pertama dengan jumlah produksi 4.673 ton, luas panen 1.200 ha dan produktivitas sebesar 3,89 ton/ha. Berdasarkan Data Monografi Desa tahun 2019, salah satu desa penghasil jagung manis yang berada di Kecamatan Sigi Biromaru adalah Desa Bulupountu Jaya dengan luas lahan 75 ha, produksi 285 ton dan produktivitas sebesar 3,80 ton/ha.

Besarnya produksi jagung manis di Desa Bulupountu Jaya belum dapat menjamin tingginya pendapatan petani, hal ini disebabkan oleh harga yang diterima petani jagung manis lebih rendah dari harga yang dibayarkan oleh konsumen. Selain itu, harga jagung manis sering mengalami fluktuasi akibat adanya panen raya. Pendapatan petani jagung manisyang relatif tidak menentu menyebabkan petani tidak mampu membeli beras yang menjadi bahan pangan pokok keluarga. Oleh sebab itu, dilakukan penelitian untuk mengetahui besarnya pendapatan yang diterima oleh petani jagung manis dan kemampuan rumah tangga petani untuk memenuhi konsumsi pangan minimum dalam hal ini beras sebagai bahan pangan pokok di wilayah penelitian sesuai dengan kebutuhan rumah tangga petani dan pendapatan rumah tangga petani.

\section{METODE PENELITIAN}

Desa Bulupountu Jaya Kecamatan Sigi Biromaru Kabupaten Sigi Provinsi Sulawesi Tengah merupakan lokasi penelitian yang dipilih secara purposive dengan pertimbangan bahwa Desa Bulupountu Jaya merupakan salah satu sentra produksi jagung manis di Kabupaten Sigi. Penelitian dilaksanakan mulai dari bulan Juli sampai dengan September 2020. Responden adalah petani jagung manis yang diambil dari populasi petani jagung manis di 
Desa Bulupountu Jaya yang berjumlah 130 orang. Penentuan responden dilakukan dengan menggunakan metode simple random sampling (pengambilan sampel acak sederhana). Apabila populasi kurang dari 100 lebih baik diambil semua hingga penelitiannya merupakan penelitian populasi. Jika jumlah populasinya lebih besar dapat diambil antara $10-15 \%$ atau $20-55 \%$ untuk derajat kepercayaan yang lebih tinggi. Dalam penelitian ini diambil $20 \%$ dari jumlah populasi (130 petani) sehingga jumlah responden menjadi 26 orang.

Data yang dikumpulkan terdiri dari data primer dan data sekunder. Data primer adalah data yang diperoleh langsung dari responden sebagai obyek penelitian (Agusta, 2014). Pengumpulan data dilakukan dengan menggunakan daftar pertanyaan (quetionnaire) sebagai alat bantu. Kuisioner digunakan ketika peneliti ingin mengetahui persepsi atau kebiasaan suatu populasi berdasarkan hasil wawancara dengan responden terkait topik yang diteliti (Jumiyati, 2019b). Sedangkan data sekunder diperoleh dari instansi-instansi yang berkaitan langsung dengan topik penelitian baik yang dipublikasikan atau tidak (Jumiyati et al., 2019). Analisis data dilakukan dengan menghitung pendapatan usahatani jagung manis berdasarkan analisis pendapatan (Mardani et al., 2017), secara matematis dirumuskan sebagai berikut:

$\pi=\mathrm{TR}-\mathrm{TC}$

Keterangan:

$\pi=$ Pendapatan $(\mathrm{Rp})$

$\mathrm{TR}=$ Total penerimaan/Total Revenue $(\mathrm{Rp})$

$\mathrm{TC}=$ Total biaya/Total Cost $(\mathrm{Rp})$

Dimana :

$\mathrm{TR}=\mathrm{P} . \mathrm{Q}$

$\mathrm{TC}=\mathrm{FC}+\mathrm{VC}$

Keterangan:

$\mathrm{P} \quad=$ Harga/Price $(\mathrm{Rp})$

$\mathrm{Q}=$ Jumlah produksi/Quantity $(\mathrm{kg})$

$\mathrm{FC}=$ Biaya tetap/Fix Cost (Rp)

$\mathrm{VC}=$ Biaya variabel/Variable Cost $(\mathrm{Rp})$

Sedangkan data tentang pendapatan non usahatani diperoleh langsung dari petani dan merupakan pendapatan rumah tangga petani selain dari usahatani jagung manis.

Selanjutnya analisis data yang yang berkaitan dengan perhitungan nilai ketahanan pangan dilakukan dengan menggunakan metode analisis deskriptif analitik (Fauzi et al., 2019), secara matematis dirumuskan sebagai berikut:

$\mathrm{Z}=\mathrm{P}(\mathrm{Q}-\mathrm{Cm})+\mathrm{N}$

Keterangan:

$\mathrm{Z}=$ Nilai ketahanan pangan

$\mathrm{P}=$ Harga pangan pokok setempat (tingkat lokal)

$\mathrm{Q}=$ Nilai pendapatan usahatani jagung manis

$\mathrm{Cm}=$ Konsumsi pangan minimum yang diperlukan

$\mathrm{N}=$ Pendapatan di luar usahatani jagung manis

Kriteria yang digunakan adalah:

a. Nilai $Z>0$, berarti terjadi ketahanan pangan rumah tangga petani

b. Nilai $Z<0$, berarti terjadi kerawanan pangan rumah tangga petani

\section{HASIL DAN PEMBAHASAN}

\section{Karakteristik Responden}

Karakteristik responden diperoleh dari wawancara langsung yang meliputi umur, tingkat pendidikan, jumlah tanggungan keluarga, pengalaman berusahatani dan luas lahan dan luas lahan yang dimiliki. Karakteristik petani merupakan suatu ciri umum yang melekat erat dengan kehidupan petani (Saputro dan Sariningsih, 2020). Berdasarkan definisi Badan Pusat Statistik (BPS), penduduk usia produktif adalah penduduk yang berusia 15-64 tahun. Sedangkan penduduk dalam usia tidak produktif adalah di bawah 15 tahun dan 65 tahun ke atas. Tenaga kerja usia produktif biasanya punya kelebihan baik dari segi stamina, fisik, serta tingkat kecerdasan dan kreativitas dikaitkan dengan perkembangan teknologi yang semakin dinamis, dan informasi yang semakin tidak terbendung, maka diperlukan sikap bijaksana dalam menanggapi perkembangan berbagai bidang kehidupan yang 
Vernando, V., Jumiyati, S., Bachri, S. : Ketahanan Pangan Rumah Tangga ...

Tabel 2. Klasifikasi umur petani jagung manis di Desa Bulupountu Jaya Kecamatan Sigi Biromaru Kabupaten Sigi

\begin{tabular}{cccc}
\hline Nomor & Klasifikasi Umur (Tahun) & Jumlah Petani (Orang) & Persentase (\%) \\
\hline 1. & $15-25$ & 0 & 0,00 \\
2. & $26-36$ & 5 & 19,23 \\
3. & $37-47$ & 9 & 34,62 \\
4. & $48-58$ & 12 & 46,15 \\
5. & $59-69$ & 0 & 0,00 \\
\hline
\end{tabular}

Sumber: Data Primer Diolah, 2020

Tabel 3. Tingkat pendidikan petani jagung manis di Desa Bulupountu Jaya Kecamatan Sigi Biromaru Kabupaten Sigi

\begin{tabular}{cccc}
\hline Nomor & Tingkat Pendidikan & Jumlah Petani (Orang) & Persentase (\%) \\
\hline 1. & SD & 6 & 23,08 \\
2. & SMP & 11 & 42,31 \\
3. & SMA & 9 & 34,61 \\
\hline & Jumlah & 26 & 100,00
\end{tabular}

Sumber: Data Primer Diolah, 2020

Tabel 4. Jumlah tanggungan keluarga petani jagung manis di Desa Bulupountu Jaya Kecamatan Sigi Biromaru Kabupaten Sigi

\begin{tabular}{cccc}
\hline Nomor & Jumlah Tanggungan Keluarga & Jumlah Petani (Orang) & Persentase $(\%)$ \\
\hline 1. & $1-2$ & 2 & 7,69 \\
2. & $3-4$ & 13 & 50,00 \\
3. & $5-6$ & 11 & 42,31 \\
\hline & Jumlah & 26 & 100,00 \\
\hline
\end{tabular}

Sumber: Data Primer Diolah, 2020

mengarah kepada kualitas sumberdaya manusian (Lubis dan Mulianingsih, 2019). Karakteristik petani jagung manis berdasarkan umur terlihat pada Tabel 2.

Berdasarkan Tabel 2, terlihat bahwa umur petani jagung manis di Desa Bulupountu Jaya tergolong petani produktif, sehingga kemampuan kerjanya relatif masih tinggi dan diharapkan dapat lebih responsive dalam menerima suatu perubahan untuk meningkatkan produksi dan pendapatan usahataninya. Klasifikasi umur petani jagung manis yang dominan adalah antara 48-58 tahun sejumlah 12 orang responden atau 46,15\%, sedangkan yang terendah adalah klasifikasi umur 26-36 tahun sejumlah 5 orang responden atau $19,23 \%$.

Tingkat pendidikan seseorang berpengaruh dalam proses pengambilan keputusan untuk peningkatan pendapatan dan menjamin kesejahteraan rumah tangga. Tingkat pendidikan berpengaruh signifikan terhadap tingkat pendapatan petani, dimana semakin tinggi tingkat pendidikan maka tingkat pendapatan juga akan meningkat (Julianto dan Utari, 2019). Karakteristik petani jagung manis berdasarkan tingkat pendidikan terlihat pada Tabel 3.

Berdasarkan Tabel 3, terlihat bahwa tingkat pendidikan petani jagung manis di Desa Bulupountu Jaya yang tertinggi adalah tingkat SMP sebanyak 11 orang responden atau $42,31 \%$, sedangkan pendidikan yang terendah adalah tingkat SD sebanyak 6 orang responden atau 23,08\%. Pesatnya perkembangan ilmu pengetahuan dan teknologi menuntut pentingnya pendidikan formal dan informal bagi petani agar dapat berperan aktif dalam menciptakan inovasi guna bersaing secara global.

Jumlah tanggungan keluarga ditentukan oleh banyaknya anggota keluarga yang menjadi tanggung jawab petani. Untuk memenuhi kebutuhan anggota keluarganya, maka petani berupaya untuk meningkatkan pendapatannya. Karakteristik petani jagung manis berdasarkan jumlah tanggungan keluarga terlihat pada Tabel 4.

Berdasarkan Tabel 4, terlihat bahwa pada umumnya petani jagung manis di Desa Bulupountu Jaya memiliki jumlah tanggungan keluarga antara 3-4 orang sebanyak 13 orang 
responden atau 50,00\%. Sedangkan yang terendah adalah jumlah tanggungan keluarga antara $1-2$ orang sebanyak 2 orang responden atau $7,69 \%$. Jumlah tanggungan keluarga sangat memengaruhi proporsi pengeluaran rumah tangga petani khususnya pengeluaran untuk pangan. Dengan demikian jumlah tanggungan keluarga dapat menjadi indikator tingkat ketahanan pangan rumah tangga petani.

Pengalaman berusahatani yaitu lamanya waktu yang dibutuhkan oleh petani dalam melakukan kegiatan usahatani. Pengalaman berusahatani bagi petani dapat menjadi penentu keberhasilan untuk masa yang akan datang. Petani yang memiliki pengalaman lebih banyak akan cenderung untuk melakukan perubahanperubahan dalam berusahatani berdasarkan pengalamannya. Karakteristik petani jagung manis berdasarkan pengalaman berusahatani terlihat pada Tabel 5 .

Berdasarkan Tabel 5, terlihat bahwa sebagian besar petani jagung manis di Desa Bulupountu Jaya memiliki pengalaman berusahatani antara 11-14 tahun sebanyak 9 orang responden atau 34,62 \%. Sedangkan yang terendah adalah pengalaman berusahatani antara 19-22 tahun sebanyak 4 orang responden atau $15,38 \%$. Tingkat pengalaman yang tinggi akan menghasilkan kerja yang lebih baik. Disamping itu, pengalaman akan mencerminkan keahlian yang dimiliki oleh seorang petani karena pengalaman berhubungan dengan keahlian dan keterampilan yang didapatkan selama berusahatani (Gustiana dan Irwanto, 2017).

Luas lahan yang digarap petani sangat berpengaruh pada produksi serta berdampak pula pada tingkat pendapatan petani. Karakteristik petani jagung manis berdasarkan luas lahan garapan terlihat pada Tabel 6 .

Berdasarkan Tabel 6, terlihat bahwa sebagian besar petani jagung manis di Desa Bulupountu Jaya memiliki luas lahan garapan antara $0,10-0,59$ ha sebanyak 16 orang responden atau $61,54 \%$. Sedangkan yang terendah adalah luas lahan garapan antara 1,001,50 ha sebanyak 4 orang responden atau $15,38 \%$. Lahan pertanian merupakan faktor utama dalam kegitan usahatani. Dengan demikian luas lahan adalah salah satu faktor produksi yang memiliki sumbangan yang cukup besar terhadap pendapatan pendapatan usahatani (Arimbawa dan Widanta, 2017).

\section{Pendapatan Usahatani Jagung manis}

Analisis usahatani dilakukan dengan mengkaji tentang cara-cara petani dalam merencanakan dan menetapkan, mengorganisasikan serta mengkoordinasikan penggunaan faktor-faktor produksi secara efektif dan efisien sehingga memberikan pendapatan maksimal. Produksi petani jagung manis di Desa Bulupountu Jaya untuk satu kali musim tanam adalah sebanyak 40,73 karung/petani atau 53,76 karung/ha dengan harga jual Rp250.000/karung. Petani menjual jagung manis dalam bentuk tongkol

Tabel 5. Pengalaman berusahatani petani jagung manis di Desa Bulupountu Jaya Kecamatan Sigi Biromaru Kabupaten Sigi

\begin{tabular}{cccc}
\hline Nomor & $\begin{array}{c}\text { Pengalaman Berusahatani } \\
\text { (Tahun) }\end{array}$ & $\begin{array}{c}\text { Jumlah Petani } \\
\text { (Orang) }\end{array}$ & $\begin{array}{c}\text { Persentase } \\
(\%)\end{array}$ \\
\hline 1. & $11-14$ & 9 & 34,62 \\
2. & $15-18$ & 8 & 30,77 \\
3. & $19-22$ & 4 & 15,38 \\
4. & $23-26$ & 5 & 19,23 \\
\hline & Jumlah & 26 & 100,00 \\
\hline
\end{tabular}

Sumber: Data Primer Diolah, 2020

Tabel 6. Luas lahan petani jagung manis di Desa Bulupountu Jaya Kecamatan Sigi Biromaru Kabupaten Sigi

\begin{tabular}{cccc}
\hline Nomor & $\begin{array}{c}\text { Luas Lahan Garapan } \\
\text { (ha) }\end{array}$ & $\begin{array}{c}\text { Jumlah Petani } \\
\text { (Orang) }\end{array}$ & $\begin{array}{c}\text { Persentase } \\
(\%)\end{array}$ \\
\hline 1. & $0,10-0,59$ & 16 & 61,54 \\
2. & $0,60-1,00$ & 6 & 23,08 \\
3. & $1,01-1,50$ & 4 & 15,38 \\
\hline & Jumlah & 26 & 100,00 \\
\hline
\end{tabular}

Sumber: Data Primer Diolah, 2020 
yang dimasukkan dalam karung. Setiap karung berisi kurang lebih 420 tongkol jagung manis. Harga jual terendah yang diterima petani di lokasi penelitian adalah Rp200.000/karung sedangkan yang tertinggi mencapai Rp400.000/karung. Petani menerima harga jual yang terendah terutama saat panen raya maka harga ditingkat petani sangat rendah. Pada saat panen raya, hasil panen berlimpah sementara permintaan konsumen tetap. Karena komoditi jagung manis mudah rusak dan akan mengurangi kualitasnya, sehingga petani terpaksa menjual hasil panennya dengan harga murah. Hal tersebut sesuai dengan karakteristik komoditas pertanian antara lain memiliki harga yang cenderung fluktuatif, bersifat musiman, ketersediaannya tergantung pada kondisi alam dan cenderung mudah rusak. Sedangkan harga tertinggi diterima oleh petani saat produksi jagung manis berkurang disebabkan sejumlah petani jagung manis tergiur menanam tanaman musiman lainnya yang harganya relatif lebih tinggi dan menguntungkan seperti tomat, cabai, bawang merah dan jenis sayur-sayuran. Sejalan dengan mekanisme pasar, jika jumlah produksi berkurang sementara permintaan relatif tetap akan menyebabkan harga jual tinggi.

Penerimaan petani jagung manis di Desa Bulupountu Jaya untuk satu kali musim tanam sebesar Rp10.182.692,31/petani atau Rp13.441.153,85/ha. Penerimaan dalam usahatani adalah total pemasukan yang diterima oleh produsen atau petani dari kegiatan produksi yang telah dilakukan dan menghasilkan uang sebelum dikurangi biaya- biaya yang dikeluarkan selama produksi. Penerimaan dalam struktur usahatani adalah perkalian antara jumlah produksi yang diperoleh dengan harga jual. Dengan demikian penerimaan ditentukan besar kecilnya produksi yang dihasilkan dan harga produksi tersebut.

Petani dalam melaksanakan usahataninya tidak terlepas dari beban biaya yang harus dikeluarkan dan diperhitungkan untuk menghasilkan produksi, dan juga merupakan semua pengorbanan yang diberikan dalam usahatani untuk memperoleh penerimaan. Biaya menurut sifatnya dibedakan menjadi dua yaitu biaya tetap (fixed cost) dan biaya tidak tetap (variable cost). Jumlah biaya tetap tidak tergantung pada besar kecilnya produksi yang dihasilkan. Sebaliknya biaya variabel diartikan sebagai biaya yang besar kecilnya dipengaruhi oleh produksi yang dihasilkan (Welang et al., 2016). Biaya tetap yang dikeluarkan oleh petani untuk satu kali musim tanam meliputi biaya pajak lahan dan penyusutan alat sebesar Rp160.462/petani atau Rp208.609/ha. Sedangkan biaya variabel yang dikeluarkan untuk satu kali musim tanam meliputi upah tenaga kerja, sewa traktor, benih, pupuk, (Urea dan NPK) serta pestisida (Furadan) sebesar Rp3.637.538,46/petani atau Rp4.786.234,82/ha. Dengan demikian biaya total yang dikeluarkan oleh petani jagung manis di Desa Bulupountu Jaya untuk satu kali musim tanam adalah sebesar Rp3.798.000,46/petani atau Rp4.994.843,82/ha.

Pendapatan merupakan hasil yang diperoleh dari jumlah penerimaan setelah

Tabel 7. Rekapitulasi penerimaan, biaya total dan pendapatan petani jagung manis di Desa Bulupountu Jaya Kecamatan Sigi Biromaru Kabupaten Sigi

\begin{tabular}{lrr}
\hline \multicolumn{1}{c}{ Uraian } & Nilai (Rp/Petani) & Nilai (Rp/ha) \\
\hline Penerimaan (TR) & $10.182 .692,31$ & $13.441 .153,85$ \\
\hline Biaya Tetap & & $10.000,00$ \\
- Pajak Lahan & $10.000,00$ & $198.609,00$ \\
- Penyusutan Alat & $150.462,00$ & $208.609,00$ \\
\hline Biaya Tetap (FC) & $160.462,00$ & \\
\hline Biaya Variabel & & $2.396 .307,70$ \\
- Tenaga Kerja & $1.815 .384,62$ & $253.846,15$ \\
- Sewa Traktor & $192.307,69$ & $1.650 .000,00$ \\
- Benih & $1.250 .000,00$ & $257.704,61$ \\
- Pupuk (Urea, NPK) & $195.230,77$ & $243.692,30$ \\
- Furadan & $184.615,38$ & $4.801 .550,76$ \\
\hline Biaya Variabel (VC) & $3.637 .538,46$ & $5.010 .159,76$ \\
\hline Biaya Total (TC) & $3.798 .000,46$ & $8.430 .994,09$ \\
\hline Pendapatan $(\pi)$ & $6.384 .691,85$ &
\end{tabular}

Sumber: Data Primer Diolah, 2020 
dikurangi jumlah biaya yang dikeluarkan pada satu kali musim tanam (Pratama, 2014). Pendapatan yang diterima oleh petani jagung manis di Desa Bulupountu Jaya untuk satu kali musim tanam berdasarkan besarnya produksi, penerimaan dan biaya total dapat dilihat pada Tabel 7.

Berdasarkan Tabel 7, terlihat bahwa penerimaan yang diterima oleh petani untuk satu kali musim tanam adalah sebesar Rp10.182.692,31/petani atau Rp13.441.153,85/ ha sedangkan total biaya produksi yang dikeluarkan oleh petani adalah sebesar Rp3.798.000,46/petani atau Rp5.010.159,76/ha. Dengan demikian pendapatan yang diterima oleh petani jagung manis di Desa Bulupountu Jaya untuk satu kali musim tanam adalah sebesar Rp6.384.691,85/petani atau Rp5.010.159,76/ha. Pendapatan yang diperoleh petani merupakan indikator yang sangat penting bagi kesejahteraan petani, karena pendapatan usahatani merupakan sumber utama dalam memenuhi kebutuhan sehari-hari baik pangan maupun non pangan. Kesejahteraan petani dapat meningkat apabila pendapatan petani lebih besar dari pada biaya yang dikeluarkan serta diimbangi dengan produksi yang tinggi dan harga yang baik (Nugraha dan Alamsyah, 2019).

\section{Ketahanan Pangan Rumah Tangga Petani Jagung Manis}

Ketahanan pangan rumah tangga petani jagung manis di Desa Bulupountu Jaya dapat dinilai berdasarkan tingkat konsumsi pangan pokok yang dapat terpenuhi berdasarkan jumlah pendapatan petani baik on farm maupun non farm. Berdasarkan data, diketahui bahwa ratarata rumah tangga petani jagung manis mengkonsumsi bahan pangan pokok beras sebanyak $734,77 \mathrm{~kg} /$ tahun dengan harga beras di tingkat lokal sejumlah Rp10.000/kg. Pendapatan yang diterima rumah tangga petani dari usahatani jagung manis sejumlah Rp6.384.691,85/tahun yang setara dengan $637,54 \mathrm{~kg}$ beras/tahun. Sedangkan pendapatan rumah tangga petani dari luar usahatani jagung manis (usaha ternak dan buruh) adalah sejumlah Rp10.223.076,92.

Kondisi ketahanan pangan rumah tangga petani jagung manis diketahui berdasarkan hasil perhitungan (nilai Z) yang diperoleh dengan menghitung selisih antara jumlah beras yang diperoleh berdasarkan jumlah pendapatan dari usahatani jagung manis $(637,54 \mathrm{~kg}$ beras/tahun) dengan jumlah beras yang dibutuhkan untuk memenuhi kebutuhan konsumsi pangan rumah tangga petani dalam satuan $\mathrm{kg} /$ tahun $(734,77 \mathrm{~kg} / \mathrm{tahun})$. Nilai selisih kemudian dikalikan dengan harga beras setempat (Rp10.000/kg) dan selanjutnya ditambahkan dengan jumlah pendapatan sampingan (Rp10.223.076,92). Berdasarkan hasil perhitungan tersebut, diperoleh nilai $\mathrm{Z}$ sebesar Rp9.250.776,92. Nilai $Z$ lebih besar daripada $1(Z>1)$ menunjukkan bahwa ratarata rumah tangga petani jagung manis di Desa Bulupountu Jaya dengan usaha sampingan akan dapat memenuhi kebutuhan pangan pokok anggota keluarga dalam setahun serta memiliki kelebihan dana sebesar Rp9.250.776,92 untuk membeli kebutuhan lain selain bahan pangan pokok (beras). Sebaliknya jika petani tidak memiliki usaha sampingan dan hanya mengusahakan tanaman jagung manis dalam satu kali musim tanam maka petani tidak akan dapat memenuhi kebutuhan pangan pokok yaitu beras dalam setahun dengan harga setempat. Nilai ketahanan pangan rumah tangga petani akan tercapai jika petani mengusahakan tanaman jagung manis untuk dua kali masa tanam dalam setahun atau memiliki pendapatan dari luar usahatani jagung manis minimal sejumlah Rp972.300.

\section{KESIMPULAN}

Pendapatan yang diterima oleh petani jagung manis di Desa Bulupountu Jaya untuk satu kali musim tanam sebesar Rp6.384.691,85/petani atau Rp5.010.159,76/Ha. Petani juga memiliki pendapatan sampingan yang berasal dari hasil penjualan ternak sapi potong dalam setahun sejumlah Rp5.007.692,31 dan akumulasi upah sebagai buruh baik buruh tani maupun buruh bangunan dalam setahun sejumlah Rp5.215.384,61 sehingga total pendapatan sampingan adalah Rp10.223.076,92. Dengan demikian ketahanan pangan rumah tangga petani jagung manis menunjukkan nilai lebih besar daripada $1(\mathrm{Z}>1)$. Hal ini menunjukkan bahwa rata-rata rumah tangga petani jagung manis dengan usaha sampingan di Desa Bulupountu Jaya akan dapat memenuhi kebutuhan pangan pokok anggota keluarga dalam setahun serta memiliki kelebihan dana 
sebesar Rp9.250.776,92 untuk membeli kebutuhan lain selain bahan pangan pokok (beras). Untuk dapat meningkatkan pendapatan dan ketahanan pangan rumah tangga, petani jagung manis sebaiknya melakukan penambahan luas lahan garapan, pengelolaan yang baik dan penanaman lebih dari satu kali dalam setahun untuk meningkatkan pendapatan terutama bagi petani dengan luas lahan garapan yang relatif sempit $(0,5$ ha) dengan jumlah tanggungan keluarga lebih dari 3 (tiga) orang. Selain itu, petani juga bisa mengupayakan agar memiliki sumber pendapatan sampingan baik dari usaha pertanian maupun non pertanian.

\section{DAFTAR PUSTAKA}

Agusta, I. (2014). Teknik pengumpulan dan analisis data kualitatif. Jurnal Studi Komunikasi dan Media, 4(2), 1-8.

Arimbawa, P. D. \& Widanta, A. B. P. (2017). Pengaruh luas lahan teknologi dan pelatihan terhadap pendapatan petani padi dengan produktivitas sebagai variabel intervening di Kecamatan Mengwi. Arimbawa Dika Putu, 6(8), 1601-1627.

Atem \& Niko, N. (2020). Persoalan kerawanan pangan pada masyarakat miskin di wilayah perbatasan Entikong (IndonesiaMalaysia) Kalimantan Barat. Jurnal Surya Masyarakat, 2(2), 94-104.

Burchi, F. \& Muro, P. D. (2012). A Human Development and Capability Approach to Food Security: Conceptual Framework and Informational Basis. Rome: United Nations Development Programme.

Fauzi, M., Kastaman, R. \& Pujianto, T. (2019). Pemetaan ketahanan pangan pada Badan Koordinasi Wilayah I Jawa Barat. Jurnal Industri Pertanian, 01(01), 1-10.

Gundersen, C., Kreider, B., \& Pepper, J. (2011). The economics of food insecurity in the United States. Applied Economic Perspectives and Policy, 33(3), 281-303. https://doi.org/10.1093/aepp/ppr022.

Gustafson, D. J. (2013). Rising food costs \& global food security: Key issues \& relevance for India. Indian Journal of Medical Research, 138(3), 398-410.

Gustianan, C. \& Irwanto, I. (2017). Pengaruh biaya produksi, pengalaman, dan keterampilan terhadap pendapatan usahatani kakao (Theobroma cacao) di Kecamatan Karang Baru Kabupaten Aceh Tamiang. Jurnal Penelitian Agrisamudra, 4(2), 67-76. https://doi. org/10.33059/jpas.v4i2.286.

Julianto, D. \& Utari, P. A. (2019). Analisa pengaruh tingkat pendidikan terhadap pendapatan individu di Sumatera Barat. Ikra-Ith Ekonomika, 2(2), 122-131.

Jumiyati, S. (2019a). Increasing income of cocoa farming through the role of agricultural extension and strengthening institutional capacity of farmers. International Journal of Agriculture, Environment and Bioresearch, 4(6), 110-121.

Jumiyati, S. (2019b). Poverty level of farmers based on total income and feasibility of rice farming. World Journal of Advanced Research and Reviews, 4(20), 082-089.

Jumiyati, S., Arsyad, M., Rajindra, R., Pulubuhu, D. A. T. \& Hadid, A. (2018). Cocoa based agroforestry: An economic perspective in resource scarcity conflict era. IOP Conference Series: Earth and Environmental Science, 575, 012009, 1-7. https://doi. org/10.1088/1755-1315/157/1/012009.

Jumiyati, S., Rajindra, R., Arsyad, M., Pulubuhu, D. A. T. \& Hadid, A. (2019). Strategy of Agrarian-Forestry Crisis Management: Participation Collaboration and Conflict. IOP Conference Series: Earth and Environmental Science, 235, 012041, 1-8. https://doi.org/10.1088/ 17551315/235/1/012041.

Lubisn, B. \& Mulianingsih, S. (2019). Keterkaitan bonus demografi dengan teori generasi. Jurnal Registratie, 1(1), $21-36$.

Mardani. T., Nur., M. \& Satriawan, H. (2017). Analisis usaha tani tanaman pangan jagung manis di Kecamatan Juli 
Kabupaten Bireuen. S. Pertanian, 1(3), 203-212.

Nugraha, S. I. \& Alamsyah, A. (2019). Factors affecting income level of rubber farmers in Village of Sako Suban Districts of Batang Hari Leko, South Sumatra. Jurnal Ilmu Pertanian Indonesia, 24(2), 93-100. https://doi.org/10.18343/jipi. 24.2.93.

Pangaribowo, E. H., Gerber, N. \& Torero, M. A. (2013). Food and nutrition security indicators: A Review. SSRN Electronic Journal. 1-50. https://doi.org/10.2139 /ssrn.2237992.

Pawlak, K. \& Kolodzjekczak, M. (2020). The role of agriculture in ensuring food security in developing countries: Considerations in the context of the problem of sustainable food production. Sustainability (Switzerland), 12(13), 5488, 1-20. https://doi.org/3390//su 12135488 .

Prabowo, R. (2010). Kebijakan pemerintah dalam mewujudkan ketahanan pangan di Indonesia. Mediagro, 6(2), 62-73.

Pratama, P. (2014). Analisis pendapatan dan kelayakan usahatani padi sawah di Desa Sidondo 1 Kecamatan Sigi Biromaru Kabupaten Sigi. E-Jurnal Agrotekbis, 2(1), 107-113.

Saliem, H. P. \& Ariani, M. (2016). Ketahanan pangan, konsep, pengukuran dan strategi. Forum Penelitian Agro Ekonomi, 20(1), 12-24. https://doi.org/10.21082/fae. v20n1.2002.12-24.

Saputro, W. A. \& Sariningsih, W. (2020). Kontribusi pendapatan usahatani kakao terhadap pendapatan rumah tangga petani di Taman Teknologi Pertanian Nglanggeran Kecamatan Pathuk Kabupaten Gunungkidul. SEPA: Jurnal Sosial Ekonomi Pertanian dan Agribisnis, 16(2), 208-217. https://doi. org/10.20961/sepa.v16i2.35825.
Suharyanto, H. (2011). Ketahanan pangan. Jurnal Sosial Humaniora, 4(2), 186-194. https://doi.org/10.12962/j24433527.v4i2. 633.

Suryana, A. (2014). Menuju ketahanan pangan Indonesia berkelanjutan 2025: Tantangan dan penanganannya. Forum Penelitian Agro Ekonomi, 32(2), 123-135. https://doi.org/10.21082/fae.v32n2.2014. 123-135.

Swastika, D. K. S. (2011). Membangun kemandirian dan kedaulatan pangan untuk mengentaskan petani dari kemiskinan. Jurnal Pengembangan Inovasi Pertanian, 4(2), 103-117.

Syahyuti, N., Sunarsih, N., Wahyuni, S., Sejati, W. K. \& Azis, M. (2016). Kedaulatan pangan sebagai basis untuk mewujudkan ketahanan pangan nasional. Forum Penelitian Agro Ekonomi, 33(2), 95-109. https://doi.org/10.21082/fae.v33n2.2015. 95-109.

Wahyunto, W., Supriatna, W. \& Agus, F. (2013). Land use change and recommendation for sustainable development of peatland for agriculture: Case study at Kubu Raya and Pontianak Districts, West Kalimantan. Indonesian Journal of Agricultural Science, 11(1), 32-40. https://doi.org/10.21082/ijas. v11n1.2010.p32-40.

Welang, F. R., Dumais, J. N. K. \& Sendow, M. M. (2016). Analisis pendapatan usahatani padi sawah berdasarkan musim panen di Kelurahan Taratara Satu Kecamatan Tomohon Barat Kota Tomohon. Agri-Sosioekonomi, 12(2), 107-124. https://doi.org/10.35791/agrso sek.12.2a.2016.12725.

Zahra, K. \& Zafar, T. (2015). Marginality as a root cause of urban poverty: A case study of Punjab. Pakistan Development Review, 54(4), 629-648. https://doi.org/ 10.30541/v54i4i-iipp.629-650. 